\title{
In vitro maturation of domestic cat oocytes subjected to different incubation times
}

\author{
Maturação in vitro de oócitos de gatos domésticos submetidos a diferentes tempos de inculbação \\ Maduración in vitro de ovocitos de gato doméstico sometidos a diferentes tiempos de incubación
}

Received: 02/18/2021 | Reviewed: 02/28/2021 | Accept: 03/04/2021 | Published: 03/10/2021

Denilsa Pires Fernandes

ORCID: https://orcid.org/0000-0001-6972-7492 Universidade Federal Rural do Semi-Árido, Brazil

E-mail: denilsas2@hotmail.com

Fernanda Araujo dos Santos

ORCID: https://orcid.org/0000-0001-6972-7492

Universidade Federal Rural do Semi-Árido, Brazil

E-mail: nanda_asantos@ @otmail.com

Luã Barbalho de Macêdo

ORCID: https://orcid.org/0000-0002-8274-8797

Universidade Federal Rural do Semi-Árido, Brazil E-mail: luanb.macedo27@gmail.com

Roberta Gonçalves Izzo

ORCID: https://orcid.org/0000-0003-3355-2111 Universidade Federal Rural do Semi-Árido, Brazil E-mail: roberta.izzo@ufersa.edu.br

Brenna de Sousa Barbosa

ORCID: https://orcid.org/0000-0002-3090-6853 Universidade Federal Rural do Semi-Árido, Brazil E-mail: brennasayuri_bs@hotmail.com

Muriel Magda Lustosa Pimentel

ORCID: https://orcid.org/0000-0002-3498-4090 Universidade Federal Rural do Semi-Árido, Brazil E-mail: murielpimentel@cesmac.edu.br Alexsandra Fernandes Pereira

ORCID: https://orcid.org/0000-0003-2137-854X Universidade Federal Rural do Semi-Árido, Brazil E-mail: alexsandra.pereira@ufersa.edu.br

Marcelo Barbosa Bezerra

ORCID: https://orcid.org/0000-0001-7368-5993

Universidade Federal Rural do Semi-Árido, Brazil

E-mail: mbezerra@ufersa.edu.br

\begin{abstract}
The aim of this study was to evaluate the effect of three different incubation times on in vitro maturation of domestic cat oocytes. Thus, ovaries $(n=42)$ were submitted to slicing procedure and the oocytes recovered were classified; only good quality oocytes (Grade I and II) underwent in vitro maturation for three different periods (24 vs. 30 vs. 36 h) in supplemented TCM-99 medium. After, oocytes were evaluated for cumulus cell expansion and presence of the first polar body. After six replicates ( $7 \pm 1,7$ ovaries per replicate), a total of 334 viable oocytes were recovered. Differences ( $\mathrm{p}<0.05)$ were observed regarding the percentage of oocytes presenting expansion of the cumulus cells, where higher values were observed in the group of oocytes incubated for $36 \mathrm{~h}(84.3 \%)$, when compared to $30(73.4 \%)$ and $24 \mathrm{~h}(71.0 \%)$. Moreover, differences were also observed regarding the presence of the first polar body ( $24 \mathrm{~h}: 29.7 \%$; $30 \mathrm{~h}: 58.2 \% ; 36 \mathrm{~h}: 69.8 \%$ ). We conclude that the incubation period influenced the maturation rates, indicating $36 \mathrm{~h}$ as the ideal period for the in vitro maturation of domestic cat oocytes in supplemented TCM-199 medium.
\end{abstract}

Keywords: Domestic feline; First polar body; Maturation; Meiotic competence.

\section{Resumo}

O objetivo deste estudo foi avaliar o efeito de três diferentes tempos de incubação na maturação in vitro de oócitos de gatos domésticos. Assim, os ovários $(\mathrm{n}=42)$ foram submetidos ao procedimento de slicing e os ovócitos recuperados foram classificados; apenas oócitos de boa qualidade (grau I e II) foram submetidos à maturação in vitro por três períodos diferentes ( 24 vs. 30 vs. 36 h) em meio TCM-199 suplementado. Em seguida, os oócitos foram avaliados quanto à expansão celular do cumulus e a presença do primeiro corpo polar. Após seis replicatas (7 $\pm 1,7$ por replicata), um total de 334 oócitos viáveis foram recuperados. Diferenças ( $p<0,05)$ foram observadas em relação à porcentagem de oócitos que apresentam expansão das células do cumulus, onde maiores valores foram 
observados no grupo de oócitos incubados por 36 h (84,3\%), quando comparados a $30(73,4 \%)$ e 24 h $(71,0 \%)$. Também foram observadas diferenças em relação à presença do primeiro corpo polar $(24 \mathrm{~h}: 29,7 \% ; 30 \mathrm{~h}: 58,2 \% ; 36$ h: $69,8 \%$ ). Concluímos que o período de incubação influenciou as taxas de maturação, indicando 36 h como o período ideal para a maturação in vitro de oócitos de gatos domésticos em meio TCM-199 suplementado.

Palavras-chave: Felino doméstico; Primeiro corpúsculo polar; Maturação; Competência meiótica.

\section{Resumen}

El objetivo de este estudio fue evaluar el efecto de tres tiempos de incubación diferentes sobre la maduración in vitro de ovocitos de gatos domésticos. Así, los ovarios $(\mathrm{n}=42)$ se sometieron al procedimiento de corte y se clasificaron los ovocitos recuperados; solo ovocitos de buena calidad (grados I y II) se sometieron a maduración in vitro durante tres períodos diferentes ( 24 frente a 30 frente a 36 h) en medio TCM-99 suplementado. Luego, se evaluaron los ovocitos para determinar la expansión de las células del cúmulo y la presencia del primer cuerpo polar. Después de seis repeticiones $(7 \pm 1,7$ por repetición), se recuperó un total de 334 ovocitos viables. Se observaron diferencias $(\mathrm{p}<0,05)$ en relación al porcentaje de ovocitos que presentan expansión celular de cúmulos, donde se observaron valores más altos en el grupo de ovocitos incubados por $36 \mathrm{~h}(84,3 \%)$, comparado con 30 (73,4 $\%)$ y $24 \mathrm{~h}(71,0 \%)$. También se observaron diferencias en relación a la presencia del primer cuerpo polar (24 h: 29,7\%; 30 h: 58,2\%; 36 h: 69,8\%). Concluimos que el período de incubación influyó en las tasas de maduración, indicando $36 \mathrm{~h}$ como el período ideal para la maduración in vitro de ovocitos de gatos domésticos en medio TCM199 suplementado.

Palabras clave: Felino domestico; Primer corpúsculo polar; Maduración; Competencia meiótica.

\section{Introduction}

In vitro maturation (IVM) of oocytes is a primordial and essential step of in vitro embryo production (IVEP), providing the necessary conditions for in vitro fertilization (IVF) and subsequent in vitro embryonic development. Under optimal culture conditions, approximately 50-79\% of immature oocytes from domestic cats reach nuclear maturation (Snoeck et al., 2016; Sowińska et al., 2016; 2017; Prochowska et al., 2019). However, these IVM rates are highly variable according to the individuality of domestic cats (Snoeck et al., 2016), and the in vitro development performance tends to decrease as the selected mature oocytes follow the IVEP process (Hribal et al., 2013; Sowińska et al., 2016). Several factors can influence IVM success, ranging from donor reproductive status to in vitro conditions, including incubation time (Nagano et al., 2008; Wlodarczyk et al., 2009; Zhong et al., 2015).

For domestic cat oocytes, the period proposed by some authors to perform IVM ranges between 24 to $44 \mathrm{~h}$ (Comizzoli et al., 2003; Demir et al., 2014; Snoeck et al., 2016; Evecen et al., 2016; Veraguas et al., 2017; Brusentsev et al. 2018). Among these, the $24 \mathrm{~h}$ interval has been preferentially employed due to laboratory logistics (Moulavi et al., 2017; Ochota \& Niżański, 2017; Kochan et al., 2018). However, the maturation rate can gradually increase over a period of 24 h (Zhong et al., 2015), and the pool of immature oocytes at different development stages may require different maturation periods (Gómez et al., 2006). In this context, it was reported that domestic cat oocyte populations undergo two "waves" of nuclear maturation, the first occurring in $26 \mathrm{~h}$ of culture and the second after 28-30 h, mimicking the in vivo copulation and ovulation given in response to induction of sexual stimulus (Johnston et al., 1989; Katska-Ksiazkiewicz et al., 2003; Gómez et al., 2006). In its turn, it has been reported that incubation for times longer than $36 \mathrm{~h}$ makes oocytes very aged, making sperm penetration difficult/unviable (Nagano et al., 2008). Therefore, a study is needed that seeks consensus on the ideal incubation period to promote oocyte maturation in the feline species.

In this context, the domestic cat is valuable as an experimental model for other felines threatened with extinction, given their phylogenetic proximity (Thongphakdee et al., 2020). Thus, IVM results data can be used to potentially preserve endangered wild felids in the era of assisted reproductive technologies. The increasing creation in commercial breeding domestic cat also supports research in the field of reproductive biology and biotechnology in this species (Pieri et al., 2015).

The investigation of intermediate IVM times, between 24 and $36 \mathrm{~h}$, is important to the optimization of results and standardization of protocol between laboratories that perform IVEP in domestic cats. This would facilitate the sharing and 
comparisons of data, and consequently, the development of biotechniques in feline species. In this perspective, the objective was to evaluate the effect of three different incubation times $(24,30$, and $36 \mathrm{~h})$ on the IVM of domestic cat oocytes.

\section{- 2. Methodology}

\section{- 2.1 ethics committee}

This study was conducted according to the recommendations of the Brazilian Code of Animal Experimentation (COBEA) (1988) and was approved by the Ethics Committee on Animal Use (CEUA) of the Federal University of Semi-Arid (UFERSA) under protocol 23091.001388/2018-65.

\subsection{Experimental animals and ovaries collection}

Twenty-one pairs of healthy ovaries (total number $=42)$ from adult $(1-3$ years old $)$ cats submitted to elective ovariohysterectomy in local veterinary clinics were used. The ovaries were transported at $4^{\circ} \mathrm{C}$ in $0.9 \% \mathrm{NaCl}$ with $0.05 \mathrm{mg} / \mathrm{mL}$ penicillin to the laboratory. The time interval between ovaries collection and processing did not exceed $5 \mathrm{~h}$ (Martins \& Lopes, 2008). Follicular, luteal, intermediate and inactive ovaries were used, and ovaries with ovarian cysts were discarded (Karja et al., 2002).

For each maturation time evaluated, six replicates were performed, and an average of seven ovaries were processed per replicate.

\subsection{Immature Oocyte Collection And Selection}

The recovery of cumulus-oophorus complexes (COCs) was performed according to the protocol described by Kunkitti et al. (2016). Briefly, the ovaries were submitted to the slicing technique, with the aid of a sterile scalpel slide, in petri dishes containing oocyte collection medium, consisting of TCM-199 supplemented with sodium bicarbonate $(2.2 \mathrm{~g} / \mathrm{L})$, bovine serum albumin (BSA; $3 \mathrm{mg} / \mathrm{mL}$ ), sodium pyruvate $(0.25 \mathrm{mg} / \mathrm{mL})$, L-glutamine $(0.15 \mathrm{mg} / \mathrm{mL})$, sodium lactate $(0.6 \mathrm{mg} / \mathrm{mL})$ and gentamicin $(0.055 \mathrm{mg} / \mathrm{mL})$.

The recovered COCs were evaluated according to the morphological classification described by Wood and Wildt (1997), and only oocytes of Grade I and II were used, namely: Grade I COCs- were oocytes with homogeneous and heavily pigmented ooplasm, surrounded by five or more layers of compacted cumulus cells; Grade II COCs- had homogeneous, heavily pigmented ooplasm, with some or a few heterogeneous granulations, encased in less than five layers of compacted cumulus cells.

\subsection{In Vitro Maturation}

After selection, the COCs were quantified and washed three times in IVM medium (oocyte collection medium supplemented with FSH/LH $(0.02 \mathrm{IU} / \mathrm{mL})$ and cysteamine $(100 \mu \mathrm{M})$. The COCs were placed in sterile Petri dishes containing drop of $100 \mu \mathrm{L}$ IVM medium covered with mineral oil at a rate of $15-20$ oocytes/drop. Maturation proceeded at $38.5^{\circ} \mathrm{C}$ with saturated humidity and atmosphere with $5 \% \mathrm{CO}_{2}$, and the $\mathrm{COCs}$ were divided into three groups according to the maturation time: 24,30 and $36 \mathrm{~h}$.

\subsection{Assessment of in vitro maturation}

The COCs submitted to IVM were observed under a stereomicroscope (20-40x magnification) and initially evaluated for cumulus cell expansion. This assessment was based on the appearance of the cumulus cells and the enlargement of cumulus 
cell mass away from the zona pellucida. The percentage of COCs presenting total cumulus cells expansion was calculated. Then, the oocytes were mechanically denuded by successive pipetting until the complete removal of the cumulus cells adhered to their zona pellucida; and visualized in the inverted microscope (400x magnification), for quantification/classification as to the presence or absence of the first polar body $\left(1^{\text {st }} \mathrm{PB}\right)$. Oocytes that presented extrusion of the $1^{\text {st }} \mathrm{PB}$ were considered matured (meiotic maturation). In addition, the percentage of oocytes activated spontaneously (with one or more cell divisions) during IVM was recorded.

\subsection{Data analysis}

The rates of IVM assessments were calculated by considering the number of oocytes that showed expansion of their cumulus cells or extrusion of the $1^{\text {st }} \mathrm{PB}$ over the total number of oocytes submitted to IVM multiplied by 100 . The spontaneously activated oocytes rate was calculated by considering the number of oocytes that presented one or more cell divisions over the total number of oocytes submitted to a given IVM period multiplied by 100 .

The data were expressed as mean in percentage \pm standard deviation (SD) for each evaluated IVM time (24 vs 30 vs $36 \mathrm{~h}$ ) and compared by the Chi-square test $(\mathrm{P}<0.05)$ using the statistical program Bioestat version 5.3.

\section{Results}

Of the total number of domestic cat ovaries evaluated, approximately 334 Grade I and II oocytes were recovered, of which $41.7 \%$ were Grade I and 58.3\% Grade II. On average, $3.3 \pm 1.3$ Grade I oocytes and $4.7 \pm 2.1$ Grade II oocytes were recovered by ovary. Grade III or IV oocytes were not counted in the study.

Table 1 presents the data regarding the IVM assessment rates for the different incubation times (24, 30 and $36 \mathrm{~h}$ ). Differences among the three IVM times were observed for both cumulus cell expansion and $1^{\text {st }} \mathrm{PB}$ extrusion $(\mathrm{P}<0.05)$.

Table 1: In vitro maturation of domestic cat oocytes after different incubation times.

\begin{tabular}{|c|c|c|c|c|c|}
\hline \multirow{3}{*}{$\begin{array}{l}\text { Incubation } \\
\text { times (h) }\end{array}$} & \multirow{3}{*}{$\begin{array}{l}\text { No. of oocytes } \\
\text { (replicate) }\end{array}$} & \multicolumn{4}{|c|}{ Evaluation of IVM (\%) } \\
\hline & & \multicolumn{2}{|c|}{ Expansion of cumulus cells } & \multicolumn{2}{|c|}{ Presence of the $1^{\text {st }} \mathrm{PB}$} \\
\hline & & Mean \pm SD & Min- Max & Mean \pm SD & Min- Max \\
\hline 24 & $117(6)$ & $71.0 \pm 7.5^{\mathrm{c}}$ & $65.0-85.7$ & $29.7 \pm 4,3^{\mathrm{c}}$ & $25.0-33.3$ \\
\hline 30 & $111(6)$ & $73.4 \pm 17.4^{b}$ & $53.3-92.8$ & $58.2 \pm 12.2^{b}$ & $46.2-70.6$ \\
\hline 36 & $106(6)$ & $84.3 \pm 7.5^{\mathrm{a}}$ & $73.3-93.8$ & $69.8 \pm 18.6^{\mathrm{a}}$ & $43.7-86.4$ \\
\hline
\end{tabular}

IVM: in vitro maturation; $1^{\text {st }}$ PB: first polar body; SD: standard deviation of the mean; Min: minimum percentage; Max: maximum percentage. a, b, c: different letters in the same column indicate different values between compared groups $(24,30$ and 36 h; P < 0.05$)$. Source: Authors (2019).

The $36 \mathrm{~h}$ of oocyte maturation reached the highest mean rate of the study for cumulus cell expansion (84.3\%) and for the presence of the $1^{\text {st }} \mathrm{PB}(69.8 \%)$, compared to the other incubation times $(\mathrm{P}<0.05)$, while the incubation for 24h showed the lowest rates in the evaluation of oocyte maturation ( $\mathrm{P}<0.05$; Table 1 ).

Cleaved oocytes and morula structures obtained by spontaneous parthenogenesis were observed for all evaluated IVM times (24, 30 and $36 \mathrm{~h}$ ). Considering all replicate, an average of 1.70\%, 2.70\% and $1.88 \%$ of spontaneous parthenogenesisactivated oocytes were observed to 24,30 and $36 \mathrm{~h}$ of IVM, respectively. 
The structural characteristics of the oocytes before and after in vitro maturation, taking into account cumulus cell expansion and the presence of the $1^{\text {st }} \mathrm{PB}$, are shown in Figure 1.

Figure 1. Structural characteristic of domestic cat oocytes before and after in vitro maturation.

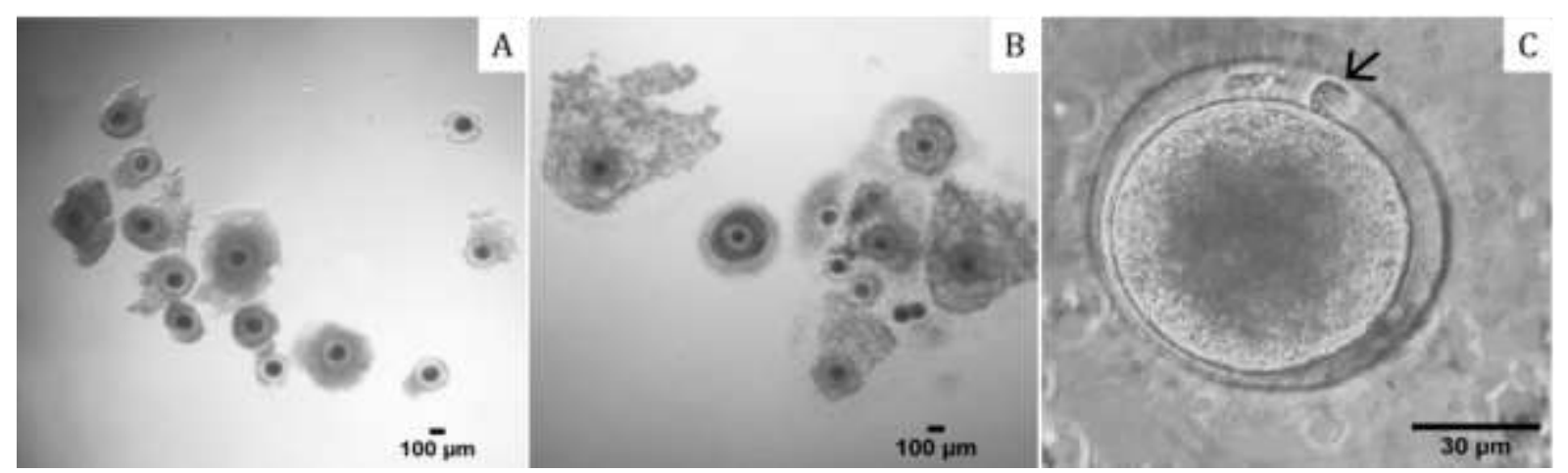

A. Oocytes before in vitro maturation, unstained, visualized in stereomicroscopy. B. Oocytes showing cumulus cell expansion after in vitro maturation, unstained, in stereomicroscopy C. Denuded oocyte showing extrusion of first polar corpuscle after in vitro maturation, unstained, visualized in an inverted microscope; Arrowhead indicates first polar body. Source: Authors (2019).

\section{Discussion}

In many species, including domestic cats (Kunkitti et al., 2016; Jewgenow et al., 2019), goats (Dos Santos et al., 2013) and cows (Otero et al., 2017), the time taken for IVM is around $24 \mathrm{~h}$, and much of this is due to the adequacy to the laboratory routine (Lonergan \& Fair, 2016). We observe a growing increase in maturation rate in relation to the $1^{\text {st }} \mathrm{PB}$ extrusion as IVM time increased $(29.7 \pm 4.3 \%, 58.2 \pm 12.2 \%$ and $69.8 \pm 18.6 \%$ for 24,30 and $36 \mathrm{~h}$, respectively), even over a longer period than the 30-34 h indicated by Fernandez-Gonzalez et al. (2015) in wild felid (Panthera leo).

In the present study, IVM for $36 \mathrm{~h}$ was ideal for domestic cat oocytes to acquire nuclear maturation, showing superiority for $1^{\text {st }} \mathrm{PB}$ extrusion rates and cumulus cell expansion over other times evaluated. Oocytes recovered from postmortem ovaries of the Indian leopard (Panthera pardus fusca), tiger (Panthera tigris tigris) and lion (Panthera leo persica) were also successfully matured to MII stage after $36 \mathrm{~h}$ of incubation (Rao et al., 2015). It was stated that some meiosis arrest factors, such as type 2 natriuretic peptide receptor (NPR-2) have a relatively longer half-life in feline oocytes (Zhong $e t$ al., 2015). Another hypothesis is that prolonged incubation time reduces the concentration of some medium constituents that may have paracrine action on factors promoting meiotic arrest, such as estradiol; it acts by activating the enzyme adenylate cyclase (AC) which in its turn promotes synthesis of cyclic adenosine 3', 5'-monophosphate (cAMP), keeping oocytes in the germinal vesicle stage (Das et al., 2017; Pan \& Li, 2019).

The 30-h period of IVM showed intermediate results, with an average nuclear maturation above $50 \%$ of cultured oocytes. Similar IVM rate $(51.8 \pm 10 \%)$ was observed by Veraguas et al. (2017) after $30 \mathrm{~h}$ of incubation. Possibly, this time promotes the maturation of a small portion of the oocytes that would be activated after $28 \mathrm{~h}$ of culture, while the others do not complete nuclear kinetics. It is reported that recovered feline oocytes may have varying degrees of immaturity, so some are in very early stages for gene activation and protein coding for meiosis resumption, such as mitogen-activated protein kinase (MAPK) and MAPK activating protein kinase (MEK), requiring longer in vitro incubation times (Johnston et al., 1989; Oliveira et al., 2009).

All IVM periods evaluated were able to trigger oocyte maturation, considering cumulus cell expansion at rates above $70 \%$. This is due to the rigorous selection and use of only Grade I and II oocytes, as it is evident that both oocytes are more likely to mature in vitro (Katska-Ksiazkiewicz et al., 2003; Wlodarczyk et al., 2009; Kunkitti et al., 2016). The protocol 
adopted allowed to reach the maximum IVM rate of $93.8 \%$ by the cumulus cell expansion in the $36 \mathrm{~h}$ period, using 6 Grade I oocytes and 10 Grade II oocytes. HighetThe results were similar to those observed by Veraguas et al. (2017), suggesting that despite the time influencing IVM rates of domestic cat oocytes, the protocol adopted in the study proves to be satisfactory in the oocyte maturation process.

Additionally, a good oocyte recovery rate was obtained for both Grade I oocytes ( $3.3 \pm 1.3$ /ovaries) and Grade II oocytes ( $4.7 \pm 2.1$ /ovaries), being this amount sufficient for the distribution between the three IVM times evaluated and considering that the proportions found in the literature are similar to the study (Wood \& Wildt, 1997; Baudi et al., 2006). Thus, it is believed that this selection played an important role in obtaining good IVM rates in this study.

Oocytes with one or more cell divisions were observed at all evaluated IVM periods. This process, called spontaneous parthenogenetic oocyte activation, can occur in appropriate media under in vitro conditions, associated with oocyte "aging", supposedly triggered by the reduction of maturation promoting factor (MPF) and MAPK activity (Jiang et al., 2015). Moreover, parthenogenetic activation in domestic cat oocytes may occur more frequently when they are matured for long periods, with a significant increase in this rate after $40 \mathrm{~h}$ of incubation (Bogliolo et al., 2004), thus, suggesting the effect of maturation time on this process. In this study, however, the spontaneously activated oocytes rate did not differ between the evaluated times. It is assumed that the occurrence of spontaneously oocyte activation may be associated with extracellular calcium concentrations present in the TCM-199 medium composition used in culture (Sun et al., 2002; Eftekhar et al., 2012). The storage time and temperature may also promote spontaneous activation of oocytes within the ovary (Kochan et al., 2018). Additionally, the spontaneously activated oocytes rates observed in this study were similar to those previously reported during IVM of oocytes after 30 and $32 \mathrm{~h}$ of incubation (2.8\% and 3.7\%, respectively) (Wolfe \& Wildt, 1996).

\section{Final Considerations}

Finally, the efficiency of IVM in domestic cats is influenced by the incubation time. The $36 \mathrm{~h}$ incubation period in TCM-199 medium provided higher nuclear maturation rates. Thus, this IVM time can be adopted in other laboratories, aiming at standardizing protocols and the improvement of oocyte maturation rate in the species. Additionally, this study can lead to future investigations regarding the evaluation of ideal IVM media and temperatures for felids.

\section{References}

Baudi, D. L. K., Spercorski, K. M., \& Morais R. N. (2006). Maturação in vitro de ovócitos de gata doméstica (Felis catus). Arch Vet Sci, $11,19-22$.

Bogliolo, L., Leoni, G., Ledda, S., Zedda, M. T., Bonelli, P., Madau, L., Santucciu, C., Naitana, S., \& Pau, S. (2004). M-phase promoting factor (MPF) and mitogen activated protein kinases (MAPK) activities of domestic cat oocytes matured in vitro and in vivo. Cloning Stem Cells, 6, 15-23.

Brusentsev, E. Kizilova, E., Mokrousova, V., Kozhevnikova, V., Rozhkova, I., \& Amstislavsky, S. (2018). Characteristics and fertility of domestic cat epididymal spermatozoa cryopreserved with two different freezing media. Theriogenology, 110, 148-152.

Comizzoli, P., Wildt, D. E., Pukazhenthi, B. S. (2003). Overcoming poor in vitro nuclear maturation and developmental competence of domestic cat oocytes during the non-breeding season. Reproduction, 126, 809-816.

Das, D., Khan, P. P., \& Maitra, S. (2017). Endocrine and paracrine regulation of meiotic cell cycle progression in teleost oocytes: cAMP at the centre of complex intra-oocyte signalling events. Gen Comp Endocr, 241, 33-40.

Demir, K., Can, A., Ertürk, E., Özdemirci, S., Karaçam, H., Sandal, A. I., Öztürk, G.B., Arici, R., Çinar, E. M., Birler, S., Pabuccuoğlu, S., Kemal, A. K., \& Evecen, M. (2014). Effect of different activation techniques on immature and in vitro matured cat oocytes. Kafkas Univ Vet Fak, $20,565-570$.

Dos Santos, E. R. J., Chaves, R. M., Lima, P. F., \& Oliveira, M. A. L. (2013). Avaliação de oócitos caprinos submetidos à estresse calórico induzido durante a maturação in vitro. Acta Sci Vet, 41, 1-7.

Eftekhar, M., Mohammadian, F., Yousefnejad, F., Khani, P., \& Aflatoonian, A. (2012). Effect of calcium ionophore on unfertilized oocytes after ICSI cycles. Iran J Reprod Med, 10, 83-86. 
Evecen, M., Pabuccuoğlu, S., Demir, K., Yağcioğlu, S., Can, A., Ertürk, E., Sandal, A. İ., Arici, R., Öztürk, G., Kemal, A. K., \& Birler, S. (2016). Somatic cloning in cats using MI or MII oocytes. Kafkas Univ Vet Fak Derg, 6, 923-928.

Fernandez-Gonzalez, L., Hribal, R., Stagegaard, J., Zahmel, J., \& Jewgenow, K. (2015). Production of lion (Panthera leo) blastocysts after in vitro maturation of oocytes and intracytoplasmic sperm injection. Theriogenology, 83, 995-999.

Gómez, M. C., Pope, C. E., \& Dresser, B. L. (2006). Nuclear transfer in cats and its application. Theriogenology, 66, $72-81$.

Hribal, R., Jewgenow, K., Braun, B. C., \& Comizzoli, P. (2013). Influence of culture medium composition on relative mRNA abundances in domestic cat embryos. Reprod Domest Anim, 48, 245-251.

Jewgenow, K., Fernandez-Gonzalez, L., Jänsch, S., Viertel, D., \& Zahmel, J. (2019). Brilliant cresyl blue staining allows the selection for developmentally competent immature feline oocytes. Theriogenology, 126, 320-325.

Jiang, H., Wang, C., Guan, J., Wang, L., \& Li, Z. (2015). Changes of spontaneous parthenogenetic activation and development potential of golden hamster oocytes during the aging process. Acta histochem, 117, 104-110.

Johnston, L. A., O'brien, S. J., \& Wildt, D. E. (1989). In vitro maturation and fertilization of domestic cat follicular oocytes. Gamete Res, $24,343-356$.

Karja, N. W. K., Otoi, T., Murakami, M., Fahrudin, M., \& Suzuki, T. (2002). In vitro maturation, fertilization and development of domestic cat oocytes recovered from ovaries collected at three stages of the reproductive cycle. Theriogenology, 57, 2289-2298.

Katska-Ksiazkiewicz, L., Ryńska, B., Kania, G., Smorąg, Z., Gajda, B., \& Pieńkowski, M. (2003). Timing of nuclear maturation of nonstored and stored domestic cat oocytes. Theriogenology, 59, 1567-1574.

Kochan, J., Agnieszka, N., Wojciech, N., Prochowska, S., Migdał, A., Młodawska, W., Partyka, A., \& Witkowski, M. (2018). Developmental competence of cat (Felis domesticus) oocytes and embryos after parthenogenetic stimulation using different methods. Zygote, 26, $119-126$.

Kunkitti, P., Axnér, E., Bergqvist, A.S., \& Sjunnesson, Y. (2016). In vitro fertilization using frozen-thawed feline epididymal spermatozoa from corpus and cauda regions. Theriogenology, 86, 1403-1408.

Lonergan, P., \& Fair, T. (2016). Maturation of oocytes in vitro. Annu Rev Anim Biosci, 4, 255-268.

Martins, L. R., \& Lopes, M. D. (2008). Fecundação in vitro no gato doméstico. Acta Sci Vet, 36, 179-186.

Moulavi, F., Hosseini, S. M., Tanhaie-Vash, N., Ostadhosseini, S., Hosseini, S. H., Hajinasrollah, M., Asghari, M. H, Gourabi, H., Shahverdi, A., Vosough, A. D., \& Nasr-Esfahani, M. H. (2017). Interspecies somatic cell nuclear transfer in Asiatic cheetah using nuclei derived from post-mortem frozen tissue in absence of cryo-protectant and in vitro matured domestic cat oocytes. Theriogenology, 90, 197-203.

Nagano, M., Uchikura, K., Takahashi, Y., \& Hishinuma, M. (2008). Effect of duration of in vitro maturation on nuclear maturation and fertilizability of feline oocytes. Theriogenology, 69, 231-236.

Ochota, M., \& Niżański, W. (2017). Time of early cleavage affects the developmental potential of feline preimplantation embryos in vitro. Theriogenology, 89, 26-31.

Oliveira, E. G., Polisseni, J., Guerra, M. O., \& Peters, V. M. (2009). Mecanismos fisiológicos e bioquímicos envolvidos na ovogênese. Rev Int Est Exp, 1, 2933.

Otero, R. A., Costa, E. P., \& Pereira, E. M. (2017). Maturação nuclear in vitro de ovócitos bovinos selecionados pelo método azul cresil brilhante. Rev Colombiana Cienc Anim, 9, 345-354.

Pan, B., \& Li, J. (2019). The art of oocyte meiotic arrest regulation. Reprod Biol Endocrin, 17, 1-12.

Pieri, N. C. G., Souza, A. F., Casals, J. B., Roballo, K. C. S., Ambrósio, C. E., \& Martins, D. S. (2015). Comparative development of embryonic age by organogenesis in domestic dogs and cats. Reprod Domest Anim, 50, 625-631.

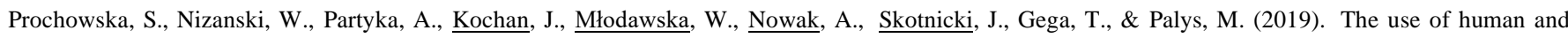
bovine commercial media for oocyte maturation and embryo development in the domestic cat (Felis catus). Reprod Domest Anim, 54, 719-726.

Rao, B. S., Mahesh, Y. U., Suman, K., Charan, K. V., Nath, R., \& Rao, K. R. (2015). Meiotic maturation of oocytes recovered from the ovaries of Indian big cats at postmortem. In Vitro Cell Dev Biol Anim, 51, 19-25.

Snoeck, F., Sarrazin, S., Wydooghe, E., \& Van Soom, A. (2016). Age and anti-Müllerian hormone levels predict the success of in vitro maturation of cat oocytes. Reprod Domest Anim, 52, 98-102.

Sowińska, N., Frankowska, K., Filipczyk, A., Adamaszek, A., Nalik, K., Fic, K., \& Pietsch-Fulbiszewska. (2016). The effect of cumulus cells on domestic cat (Felis catus) oocytes during in vitro maturation and fertilization. Reprod Domest Anim, 52, 108-113.

Sowińska, N., Müller, K., Niżański, W., \& Jewgenow, K. (2017). Mitochondrial characteristics in oocytes of the domestic cat (Felis catus) after in vitro maturation and vitrification. Reprod Domest Anim, 52, 806-813.

Sun, X. S., Yue, K. Z., Zhou, J. B., Chen, Q. X., \& Tan, J. H. (2002). In vitro spontaneous parthenogenetic activation of golden hamster oocytes. Theriogenology, 57, 845-851.

Thongphakdee, A., Sukparangsi, W., Comizzoli, P., \& Chatdarong, K. (2020). Reproductive biology and biotechnologies in wild felids. Theriogenology, 150, $360-373$. 
Research, Society and Development, v. 10, n. 3, e15710313074, 2021

(CC BY 4.0) | ISSN 2525-3409 | DOI: http://dx.doi.org/10.33448/rsd-v10i3.13074

Veraguas, D., Gallegos, P. F., Velasquez, A. E., Castro, F. O., \& Rodriguez-Alvarez, L. (2017). FSH stimulation of anestrous cats improves oocyte quality and development of parthenogenetic embryos. Theriogenology, 87, 25-35.

Wlodarczyk, R., Bukowska, D., Jackowska, M., Mucha, S., \& Jaskowski, J.M. (2009). In vitro maturation and degeneration of domestic cat oocytes collected from ovaries stored at various temperatures. Vet Med-Czech, 54, 491-497.

Wolfe, B. A., \& Wildt, D. E. (1996). Development to blastocysts of domestic cat oocytes matured and fertilized in vitro after prolonged cold storage. J Reprod Infertil, 106, 135-141.

Wood, T. C., \& Wildt, D. E. (1997). Effect of the quality of the cumulus-oocyte complex in the domestic cat on the ability of oocytes to mature, fertilize and develop into blastocyst in vitro. J Reprod Infertil, 110, 355-360.

Zhong, Y., Lin, J., Liu, X., Hou, J., Zhang, Y., \& Zhao, X. (2015). C-Type natriuretic peptide maintains domestic cat oocytes in meiotic arrest. Reprod Fertil Dev, 28, 1553-1559. 